\title{
The Weekend Effect in African Stock Markets
}

\section{Brinwa Kra}

Judd Leighton School of Business

Indiana University South Bend

1700 W Mishawaka Ave., South Bend, IN, 46615

Email: brinkra@iu.edu

USA

Xing Lu $\mathbf{L u}^{1}$

Judd Leighton School of Business

Indiana University South Bend

1700 W Mishawaka Ave., South Bend, IN, 46615

Email: Lu35@iusb.edu

USA

\section{Haiyan Yin}

Judd Leighton School of Business

Indiana University South Bend

1700 W Mishawaka Ave., South Bend, IN, 46615

Email: Haiyin@iusb.edu

USA

\section{Abstract}

This study investigates daily stock market anomalies in the African stock markets, using two most representative stock index ETFs, each over at least eleven-year time period spanning from pre-financial crisis era to ten years into the financial crisis. This research attempts to test the presence of the weekend effect on stock returns in the African stock exchanges during the financial crisis. The results indicate a significant negative effect on Mondays. Our results shed some light on the degree of market efficiency in one of the major emerging capital markets in the world.

\section{Keywords: Monday Effect, Weekend Effect, African stock market}

\section{JEL classification: C31, G11, G14}

\section{Introduction}

The weekend Effect anomalies have been well documented in stock returns from the U.S., European and Asian financial markets. Earlier Studies exploring the weekend effect include Cross (1973), French (1980), Gibbons and Hess (1981), Keim and Stambaugh (1984), Aggarwal and Rivoli(1989), and Rogalski (1984), all showing that the distribution of stock returns varies according to the weekend. Bashaer and Sadorsky (2006) suggest that identifying the weekend effect in financial markets is very crucial for investors to make decisions with their portfolio adjustment. First, many studies show that Monday has been the "underperforming" day, as the returns on Monday tend to be negative and significantly lower than the average return of other weekdays (Gibbons and Hess 1981; Jaffe and Westerfield 1985; Solnik and Bousquet 1990; Siegel 1998). Second, although less common than the Monday effect, a few studies find higher stock index returns occurring on Friday (Lakonishok and Smidt 1988). These effects are not limited to the U.S.

\footnotetext{
${ }^{1}$ Corresponding author, Xing Lu Email: Lu35@iusb.edu
} 
equity market, but also found in other financial markets including the futures market, Treasury bill market, real estate investment trusts, currency exchange market, and the bond market (Cornell 1985; Dyl and Maberly 1986; Redman, Manakyan, and Liano 1997; Thatcher and Blenman 2001). The weekend effect has also been found significant in many other countries (Aggarwal and Rivoli 1989; Chang, Pinegar and Ravichandran 1993; Dubois and Louvet 1996; Tong 2000; Lu and Gao 2016). Jaffe and Westerfield (1985) find a similar but not identical effect in China, Japan, Australia, Canada, and the United Kingdom. Chen and Singal (2003) identify the trading behavior of short-sellers as the possible cause of negative Monday returns. They argue that speculative short-sellers seek to closely monitor their positions to limit potential losses by closing their open position before the weekend. However, short selling should not be impactful in causing the positive Friday returns in the African stock market, since short-selling stocks are extremely limited.

This paper attempts to investigate the weekend effect in Africa, especially after the inception of the 2008 financial crisis. Since the inception of the financial crisis in 2008, the foreign investments to Africa have significantly increased from the U.S, as shown in Figure 1.

\section{Figure 1 U.S.'s FDI in Africa (2000-2018)}

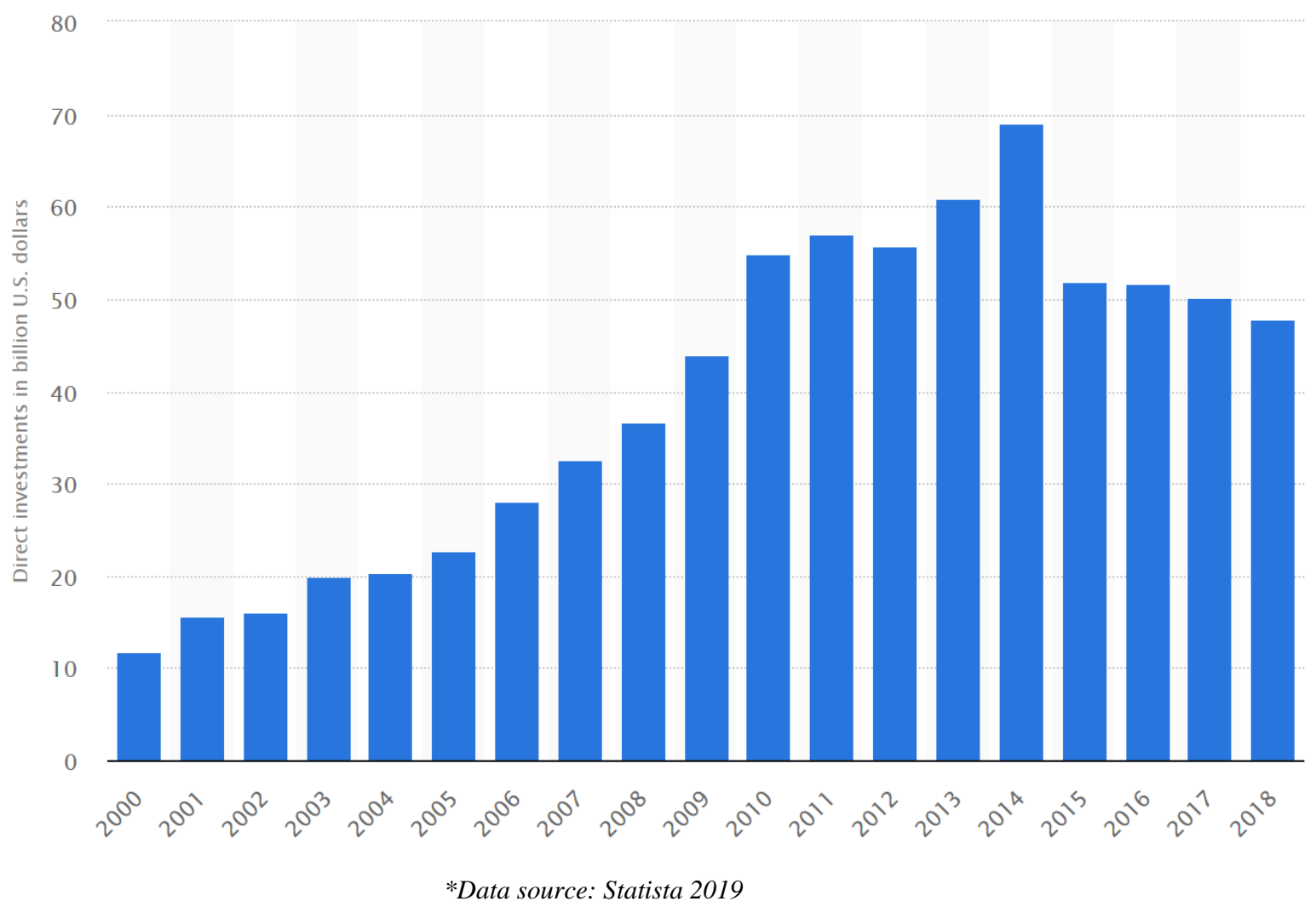

In this paper, our data sample spanning from 2003 to 2019, enables us to investigate the weekend effects before and after the inception of the global financial crisis. We use daily values of two most representative indices tracking large and mid-cap companies in Africa, in our attempt to identify the weekend effect. We test two hypotheses in this paper:

H1. The weekend effect is significant in African stock markets.

H2. The increased bond between Africa and the U.S. financial markets causes a stronger Monday effect in African stock markets.

The remainder of the paper is organized as follows: Section II describes the data sample and methods. Section III presents and discusses the empirical results. Finally, we summarize the findings in the last section. 


\section{Data and Methodology}

Our study includes two very representative African stock index ETFs, as shown in Table I. All data are collected from Yahoo! Finance's database. The sample periods range from 2003 to 2019.

Daily market returns of the major stock market indices have been computed and categorized based on the occurrence of the global financial crisis. The global financial crisis splits the full sample into two groups by Sept. 15th, 2008, when the bankruptcy of Lehman Brothers was announced.

Table I. Index ETF Descriptions

\begin{tabular}{|l|l|l|}
\hline \multicolumn{1}{|c|}{ ETF } & \multicolumn{1}{|c|}{ Tracking Index } & \multicolumn{1}{c|}{$\begin{array}{c}\text { Inception Date in } \\
\text { Our Sample }\end{array}$} \\
\hline $\begin{array}{l}\text { Van Eck Vectors Africa } \\
\text { Index ETF (AFK) }\end{array}$ & $\begin{array}{l}\text { MVIS GDP Africa Index : defines } \\
\text { country weightings based on a } \\
\text { country's gross domestic product } \\
\text { (GDP). }\end{array}$ & Jul. 14 th $^{\text {G }} 2008$ \\
\hline $\begin{array}{l}\text { iShares MSCI South } \\
\text { Africa ETF (EZA) }\end{array}$ & $\begin{array}{l}\text { MSCI South Africa 25/50 } \\
\text { Index : large and mid-cap equity }\end{array}$ & Feb. $7^{\text {th }} 2003$ \\
\hline
\end{tabular}

We calculate the returns of the indices using the formula:

where

$$
R_{t}=\operatorname{Ln}\left(P_{t}\right)-\operatorname{Ln}\left(P_{t-1}\right)
$$

- Rt is the return on the day $\mathrm{t}$;

- Pt is the closing market index price on the day $\mathrm{t}$.

We test the weekend effects by forming the regression model with dummy variables:

where

$$
\mathrm{R}_{\mathrm{t}}=\beta_{1} \text { Mon }_{\mathrm{t}}+\beta_{5} \mathrm{Fri}_{\mathrm{t}}+\mathrm{e}_{\mathrm{t}}
$$

- $\mathrm{R}_{\mathrm{t}}$ is the index return on day $\mathrm{t}$;

- Mon ${ }_{t}$ is a dummy variable which equals one for Monday and zero otherwise;

- Frit is a dummy variable which equals one for Friday and zero otherwise;

If the African stock market exhibits a stronger negative Monday effect, then the estimated coefficient $\beta_{1}$ is expected to be negative and statistically significant.

\section{Testing Weekend Effects}

Table II presents the descriptive statistics of index returns. The K-W test suggests the presence of a significant negative Monday anomaly for both indices. Besides, the magnitude of the negative mean return on Mondays in South Africa became much stronger after the financial crisis.

\begin{tabular}{|c|c|c|c|}
\hline Index & Return & Mean (Std. Dev.) & K-W Test [p-value] \\
\hline \multirow[t]{5}{*}{ AFK } & Monday & $-.0003(.0068)$ & $5.160[0.023]^{* *}$ \\
\hline & Friday & $.0001(.0061)$ & $.031[.565]$ \\
\hline & \multicolumn{3}{|c|}{ After Financial Crisis } \\
\hline & Monday & $-.0003(.0068)$ & $4.509[.034]^{* *}$ \\
\hline & Friday & $.0001(.0061)$ & $.278[.598]$ \\
\hline \multirow[t]{5}{*}{ EZA } & Monday & $-.0001(.0091)$ & $2.941[.086]^{*}$ \\
\hline & Friday & $.0002(.0087)$ & $.482[.487]$ \\
\hline & \multicolumn{3}{|c|}{ After Financial Crisis } \\
\hline & Monday & $-.0002(.0096)$ & $3.25[.071]^{*}$ \\
\hline & Friday & $.0001(.0094)$ & $.074[.786]$ \\
\hline
\end{tabular}

Table II. Descriptive Statistics 
Table III reports the regression results. AFK shows a strong negative Monday effect. The negative effect is significant at 5\% level, and consistent with the statistics in Table II, where the Monday mean is negative. However, although EZA shows an increased negative mean return in Table II, the negative Monday effect is not significant. After the inception of the 2008 financial crisis, results are similar to the full sample results.

Table III. Regression Results

\begin{tabular}{|c|c|c|}
\hline Index & Return & Coefficient [p-value] \\
\hline \multirow[t]{5}{*}{ AFK } & Monday & $-.0016[.027] * *$ \\
\hline & Friday & $.0004[.558]$ \\
\hline & \multicolumn{2}{|c|}{ After Financial Crisis } \\
\hline & Monday & $-.0015[.035]^{* *}$ \\
\hline & Friday & $.0004[.601]$ \\
\hline \multirow[t]{5}{*}{ EZA } & Monday & $-.0010[.256]$ \\
\hline & Friday & $.0004[.46]$ \\
\hline & \multicolumn{2}{|c|}{ After Financial Crisis } \\
\hline & Monday & $-.0011[.311]$ \\
\hline & Friday & $.0002[.843]$ \\
\hline
\end{tabular}

\section{Conclusion and Summary}

In this research, we intend to answer three questions: first, do weekend effects exist and persist in African stock exchanges? Second, how does the financial crisis impact the weekend effect?

We find that the weekend effects have been strong and significant in African stock exchanges. Our descriptive statistics of AFK show a consistent pattern of negative returns on Monday, which is supported by the Kwallis-White test with a 5\% significance level. This effect has remained strong before and after the 2008 financial crisis. The regression analysis results also support this effect, showing a negative coefficient on the Monday factor and significant at 5\% level. EZA also shows a strong negative Monday effect, which is significant at the $10 \%$ level. However, while the EZA's mean returns on Monday became further negative, the regression results show that the weekend effect remains the same after the financial crisis.

\section{References}

Aggarwal, R., and P. Rivoli. (1989). Seasonal and Day-of-the Week Effects in Four Emerging Stock Markets. Financial Review 24: 541-550.

Aoki, Y., Liu, D., Sun, S., Wang, T., Wang, X., \& Zhou, A. (2013). African Foreign Direct Investment in the United States. Colubmia University, Working Paper.

Basher, S. A. and Sadorsk, P. (2006) "Day-of-the-week effects in emerging stock markets, Applied Economics Letters, 13, pp. 621-628.

Chang, E., Pinegar J., \& Ravichandran R. (December 1993). International Evidence on the Robustness of the Day-of-the-Week Effect. Journal of Financial and Quantitative Analysis, pp. 497-513.

Chen, G., Kwok C.Y., \& Rui O. (2001). The Day-of-the-Week Regularity in the Stock Markets of China. Journal of Multinational Financial Management, Vol. 11, pp. 139-63.

Chen, G., Lee B., \& Rui O. (2001). Foreign Ownership Restrictions and Market Segmentation in China's Stock Markets. Journal of Financial Research, Vol. 24, pp. 133-55.

Chen, H., \& Singal V. (April 2003). Role of Speculative Short Sales in Price Formation: Case of the Weekend Effect. Journal of Finance, pp. 685-705.

Chui, A., \& Kwok C.Y. (1998). Cross-Autocorrelation between A Shares and B Shares in the African Stock Market. Journal of Financial Research, Vol. 21, pp. 333-53. 

583-88.

Cornell, B. (1985). The Weekly Patterns in Stock Returns Cash versus Futures: A Note. Journal of Finance 40: 69.

Cross, F. (1973). The Behavior of Stock Prices on Fridays and Mondays. Financial Analysts Journal 29: 67-

DuBois, M., \& Louvet P. (November 1996). The Day-of-the-Week Effect: The International Evidence. Journal of Banking and Finance, pp. 1463-1484.

Dyl, E., \& Maberly E. (1986). The Daily Distribution of Changes in the Price of Stock Futures. Journal of Futures Markets 6: 513-521.

French, K. R. (1980). Stock Returns and The Weekend Effect. Journal of Financial Economics 8:55-69.

Gibbons, M., \& Hess P. (1981). Weekend Effects and Asset Returns. Journal of Business 54: 579-596.

Jaffe, J., and Westerfield R. (1985). "The Weekend Effect in Common Stock Returns: The International Evidence.” Journal of Finance 40: 433-454.

Keim, D. B., \& Stambaugh F. (1984). A Further Investigation of Weekend Effects in Stock Returns. Journal of Finance 39: 819-840.

Lakonishok, J., \& Smidt S. (Winter 1988). Are Seasonal Anomalies Real? A Ninety Year Perspective, Review of Financial Studies, pp. 403-425.

Lu, X., \& Gao, H. (2016). The Day of the Week Effect in Chinese Stock Market. Journal of Asian Finance, Economics, and Business, 3(3), 17-26.

Ma, X. (1996). Capital Controls, Market Segmentation and Stock Prices: Evidence from the African Stock Markets. Pacific Basin Finance Journal, Vol. 4, pp. 219-39.

Mookerjee, R., \& Qiao Y. (1999). An Empirical Analysis of the Equity Markets in China. Review of Financial Economics, Vol. 8, pp. 41-60.

Poulsen, L., \& Hufbauer, G. (2011). Foreign Direct Investment in Times of Crisis. LSE Working Paper Series. Redman, A., Manakyan H., \& Liano K. (1997). Real Estate Investment Trusts and Calendar Anomalies. Journal of Real Estate Research, pp. 19-28.

Rogalski, R. J. (1984). New Findings Regarding Day-of-the-Week Returns over Trading and Non-Trading Periods: A Note. Journal of Finance, 35: 1603-1614.

Siegel, J. (1998). Stocks for the Long Run. New York: McGraw Hill.

Solnik, B., \& Bousquet L. (1990). Day-of-the-Week Effect on the Paris Bourse. Journal of Banking and Finance, 14: 461-468.

Thatcher, J., and Blenman L. (May 2001). Synthetic Trades and Calendar Day Patterns: The Case of the Dollar/Sterling Markets. Financial Review, pp. 177-200. 495-522.

Tong, W. (Winter 2000). International Evidence on Weekend Anomalies. Journal of Financial Research, pp.

Xu, C. (2000). The Microstructure of the African Stock Market. China Economic Review, Vol. 11, pp. 79-97. 